\title{
THE EFFECT OF MS-222 ON THE CARDIAC AND RESPIRATORY FUNCTION AND BEHAVIOUR OF COMMON CARP, CYPRINUS CARPIO L., DURING GENERAL ANAESTHESIA
}

\author{
Robert DZIAMAN*, Bernard KŁYSZEJKO, Grzegorz HAJEK \\ Division of Fish Physiology, Agricultural University of Szczecin, Szczecin, Poland
}

Dziaman R., Kłyszejko B., Hajek G. 2005. The effect of MS-222 on the cardiac and respiratory function and behaviour of common carp, Cyprinus carpio L., during general anaesthesia. Acta Ichthyol. Piscat. 35 (2): $125-131$.

Background. Assessments of the efficacy of anaesthetics are usually based on observations of fish behaviour or changes in blood parameters. In this study we attempted to assess the process of anaesthesia, caused by MS-222, based on the measurement of heartbeat and respiratory frequency.

Material and methods. The effect of four concentrations of MS-222 $\left(75,100,125\right.$, and $\left.150 \mathrm{mg} \cdot \mathrm{L}^{-1}\right)$ on heartbeat and respiratory frequency of common carp, Cyprinus carpio L., were studied using ECG. Concurrently (during general anaesthesia) fish behaviour was also observed.

Results. The behavioural reactions were similar for all four treatments. The first symptom was agitation followed by sedation, loss of equilibrium, and deep anaesthesia. Small differences were observed during initial contact of fish with the anaesthetic. The ECG analysis, however, revealed significant differences in heartbeat and respiratory frequencies related to the concentration used. Irrespective of the MS-222 concentration used, the recovery time was similar in all treatments and did not exceed 5 minutes.

Conclusion. The ECG method can be an important and objective tool supplementing the data acquired during visual observations of responses to anaesthesia. Its major advantage is the comparativeness of data.

Key words: fish, Cyprinus carpio, common carp, anaesthesia, ECG, respiration, MS-222, tricaine, heart rate

\section{INTRODUCTION}

Anaesthetics used in aquaculture are intended to limit stress reactions of fishes, diminish transportation losses, and facilitate rearing, sanitary, or surgical procedures. They also have an ethical aspect, i.e. making the abovementioned activities more humane. The efficacy of an anaesthetic may be assessed based on visual observation of fish behaviour such as movements and changes in reactivity. These responses are usually qualitative and are often described variably by different authors.

The aim of this study was to link the observed behavioural changes in the course of fish anaesthesia with concurrent functional responses in cardiac and respiratory rhythms.

\section{MATERIAL AND METHODS}

The experiments were carried out on 44 carp, Cyprinus carpio L., $(210 \pm 74 \mathrm{~g})$ taken from a cage-culture facility located on the warm-water discharge canal of the "Dolna Odra" power plant at Gryfino, near Szczecin, Poland. The fish were acclimated to the new environment for 14 days in a large 1000-L aquarium, in aerated tap water, at $20 \pm$ $1^{\circ} \mathrm{C}(\mathrm{pH}=7.5)$.

The fish were subjected to a general anaesthesia using MS-222 (synonyms: tricaine mesilate, tricaine methanesulfonate, $m$-aminobenzoic acid ethyl ester methansulfonate), manufactured by ICN Biomedicals Inc. Ohio, USA. In many countries MS-222 is the only anaesthetic agent licensed for finfish intended for human consumption and for ornamental fish. The $\mathrm{pH}$ of the stock solution of MS-222 $\left(10 \mathrm{~g} \cdot \mathrm{L}^{-1}\right)$ was adjusted to 7.0 using sodium bicarbonate.

The experiment consisted of 4 treatments (11 fish each) involving concentrations: $75,100,125$, and $150 \mathrm{mg} \cdot \mathrm{L}^{-1}$ of water. Each fish was treated on individual basis.

The heartbeat and respiratory frequency were recorded with the aid of ECG equipment manufactured by CED (Cambridge Electronic Design Limited, England). This complex setup consisted of the module MICRO 1401, linked to the signal amplifier CED 1902. Both units were controlled by SPIKE 2 (ver. 3) computer software. ECG

\footnotetext{
* Correspondence: Dr Robert Dziaman, Zakład Fizjologii Ryb, Wydział Nauk o Żywności i Rybactwa, Akademia Rolnicza w Szczecinie, ul. Kazimierza Królewicza 4, 71-550 Szczecin, Poland, phone: (+48) 091423 1061, e-mail: bob@fish.ar.szczecin.pl
} 
readings were recorded using a two-pole wiring system, following Labat's (1966) method. The copper electrodes used were elastic and $1 \mathrm{~mm}$ in diameter. Their electrical insulation was removed along the last $5-6 \mathrm{~mm}$ and the electrodes were silvered to ensure correct conductivity. The electrodes penetrated the abdominal wall with their exposed parts placed in the pericardium and their isolated proximal ends protruding outside the fish. The elastic connection of the electrodes to the recording unit enabled the fish to move freely within the experimental aquarium.

The electrodes were implanted following general anaesthesia with Propiscin (etomidate) at $1.5 \mathrm{~mL} \cdot \mathrm{L}^{-1}$. After determining their correct position in relation to the heart, the electrodes were permanently mounted ventrally and dorsally using rubber bands and the fish was placed in an experimental tank, made of dark glass and illuminated from above by a glow-tube. One of the tank walls was a Venetian mirror, which facilitated discrete observation of the fish.

After 24 hours the recording units were switched on in a constant monitoring mode. The first recorded 15 minutes served as control and subsequently the anaesthetic was added to the water. After further 15 minutes the anaesthetised fish were transferred to an identical aquarium, with clean, clear and well aerated water where the vital parameters were monitored for another 15 minutes.

A total of four treatments was carried out under the same conditions $\left(20 \pm 0.5^{\circ} \mathrm{C}, \mathrm{pH}=7.5\right.$, constant aeration and illumination).

The results were processed statistically using STATISTICA 6.0 PL. To assess the significance of differences between control values and the values in individual minutes of the experiment, a non-parametric Mann-Whitney test was used. The magnitudes of relationships between the respiratory and heartbeat rhythms were determined using Pearson's linear correlation coefficient.

This experimental protocol was approved by the Local Ethical Committee for Experiments on Animals (Agricultural University of Szczecin, Poland)

\section{RESULTS}

Results of the visual observations of carp behaviour under influence of MS-222 are given in Table 1.

The cardiac and respiratory responses of fish exposed to MS-222 are presented in the form of graphs (Figs. 1-6)

In the treatment with MS-222 at $75 \mathrm{mg} \cdot \mathrm{L}^{-1}$ (Fig. 1), within the first few minutes of exposure, there was a transient decrease in the heartbeat and respiratory frequencies. After some 2 minutes of exposure, there was an increase in the heartbeat frequency that persisted to the end of exposure. This tachycardia was accompanied by increased ventilation. During the recovery period, the respiratory rhythm resembled that recorded for control (ca. 60 cycles per min).

Within the first minute of exposure to $100 \mathrm{mg} \cdot \mathrm{L}^{-1}$ (Fig. 2), there was a transient decrease in the heartbeat frequency and slight decrease in the respiratory frequency. On average, after 2 min of exposure, the heartbeat accelerated, to reach 64 beats per min in the 4 th min of exposure. There was a concurrent increase in the respiratory frequency.
Within the first few minutes of exposure to $125 \mathrm{mg} \cdot \mathrm{L}^{-1}$ (Fig. 3), there was a transient decrease in heart rate followed by its acceleration up to ca. 50 cycles per min, persisting until the end of the exposure. The respiratory frequency decreased briefly within the first minute of exposure and than increased, reaching its maximum value (47 operculum movements per min) in the 3rd min of exposure. During recovery, the respiratory frequency slowly decreased.

Exposure to $150 \mathrm{mg} \cdot \mathrm{L}^{-1}$ (Fig. 4) resulted in a sudden decrease in respiratory frequency down to 25 operculum movements per min. In the 2 nd (on average) minute of exposure the respiratory rhythm distinctly increased, reaching ca. 80 operculum movements per min, but then rapidly decreased. The 11th min of exposure marked a total arrest of the respiratory rhythm.

Immediately after exposure to $150 \mathrm{mg} \cdot \mathrm{L}^{-1}$ a strong bradycardia was also observed. In the second minute of exposure the heart rate decreased down to 20 beats per min. After ca. 2 min the heartbeat distinctly accelerated, reaching the highest value (within 3rd and 5th min of exposure) and then it gradually slowed until the end of 15min exposure. During recovery in clean water, the ventilation rapidly increased and the heartbeat regained the rates recorded at control.

The readings of the heart's electrical function, recorded before anaesthesia and assumed as control, exhibited all the expected ECG components of higher vertebrates. Considering minimal differences, during implantationin the positioning of electrodes in relation to the heart and also the arrangement of the heart in relation to its own axis-in all cases positive $\mathrm{P}, \mathrm{R}$, and $\mathrm{T}$ waves were obtained, as well as Q and $\mathrm{S}$ waves, situated with their peaks below the isoelectric line. The anaesthesia caused statistically significant changes in the ECG curve, regarding its shape and amplitude of the $\mathrm{T}$ wave. The recorded changes were similar for all four tested concentrations of MS-222 and are presented in Fig. 5.

Times of losing and regaining locomotor equilibrium are shown in Table 2.

\section{DISCUSSION}

Traditional (visual) monitoring of the course of anaesthesia in carp revealed that a common feature at all tested concentrations of MS-222, was a distinct locomotor agitation. This was usually associated with a short (few seconds) apnoea and "cough" in lower concentrations $(75,100$, and $\left.125 \mathrm{mg} \cdot \mathrm{L}^{-1}\right)$. At the highest concentration $\left(150 \mathrm{mg} \cdot \mathrm{L}^{-1}\right)$, a period of "gasping for air" was observed. These symptoms indicate that the tested concentrations of MS-222 irritated the gill epithelium and hindered gas exchange.

Published opinions on effects of $\mathrm{pH}$ on the behaviour of fishes exposed to MS-222 are not consistent. Non-buffered MS-222 is acidic, and Wedemeyer (1970) observed that a $\mathrm{pH}$ decrease caused by MS-222 increased fish mobility and accelerated their heartbeat. Soivio et al. (1977), however, did not observe this when studying marine fishes in seawater. The latter authors also did not observe any agitation of 
Carp behaviour under various concentrations of MS-222

\begin{tabular}{|c|c|}
\hline $\begin{array}{l}\text { MS-222 } \\
\text { concentration } \\
{\left[\mathrm{mg} \cdot \mathrm{L}^{-1}\right]}\end{array}$ & Behavioural responses \\
\hline 75 & $\begin{array}{l}\text { Agitation; fish swim fast, exhibit distinct defensive reflexes; irregular } \\
\text { respiratory rhythm. } \\
\text { Agitation; accelerated, irregular respiration; regular "cough" every 4th } \\
\text { breath. } \\
\text { Loss of equilibrium, rhythmic but shallow breath; fish sink to the bottom. } \\
\text { Deep anaesthesia; shallow breath; fish lie on the bottom; do not show } \\
\text { defensive reflexes. }\end{array}$ \\
\hline 100 & $\begin{array}{l}\text { Agitation; fish exhibit distinct defensive reflexes, swim fast and nervously. } \\
\text { Faster, irregular breath; regular "cough" every 4th breath. } \\
\text { Loss of equilibrium, shallow breath; fish tip over on their sides and sink to } \\
\text { the bottom of aquarium. } \\
\text { Deep anaesthesia; fish lie on the bottom; shallow breath. }\end{array}$ \\
\hline 125 & $\begin{array}{l}\text { Agitation; fish exhibit distinct defensive reflexes, swim nervously. } \\
\text { - Faster, irregular breath; regular "cough"; sporadically signs of "gasping for } \\
\text { air". } \\
\text { Calming down; fish swim tilted to their sides. } \\
\text { - Shallow, irregular breath; loss of equilibrium; fish sink to the bottom. } \\
\text { Deep anaesthesia; fish lie on their sides on the bottom; exhibit no defensive } \\
\text { reflexes; shallow, irregular breath. }\end{array}$ \\
\hline 150 & $\begin{array}{l}\text { Distinct agitation; fish swim fast; exhibit distinct defensive reflexesirregular } \\
\text { respiratory rhythm. } \\
\text { Strong agitation; faster, irregular breath; signs of "gasping for air". } \\
\text { Loss of equilibrium; fading of respiratory movements; fish sink to the } \\
\text { bottom; } \\
\text { Deep anaesthesia; fish lie on their sides on the bottom; do not breathe; } \\
\text { exhibit no defensive reflexes }\end{array}$ \\
\hline
\end{tabular}

freshwater fish sedated using buffered MS-222. Our study revealed the increase of agitation during the first few minutes of exposure to buffered MS-222.

A number of authors, particularly the pioneers of fish anaesthesia (McFarland 1960, Schoettger and Julin 1967, Ross and Ross 1984), suggested the need for a species-specific approach, taking into consideration biological adaptations, type of anaesthetic, and environmental factors. However, the behavioural reactions of different fish species during their contact with anaesthetics are quite similar and the number of possible responses is limited. Another weak point of the assessment of behavioural responses is the descriptive method used, which is particularly evident in locomotor reactions, responses to acoustic or pain stimuli, etc.

Concurrent with visual observation of behavioural responses, heartbeat and respiratory frequencies were recorded in this study. The recordings showed that immediately after adding MS-222 to the water, heart rate showed a temporary decrease. This decrease in the first minutes of exposure was particularly distinct ( 20 cycles per min) at the highest anaesthetic concentration $\left(150 \mathrm{mg} \cdot \mathrm{L}^{-1}\right)$, and was accompanied by a strong locomotor agitation and a decreased respiratory frequency. This was followed by acceleration of the heart rate to the level persisting throughout the entire experiment (for concentrations of 75,100 , and $125 \mathrm{mg} \cdot \mathrm{L}^{-1}$ ). 


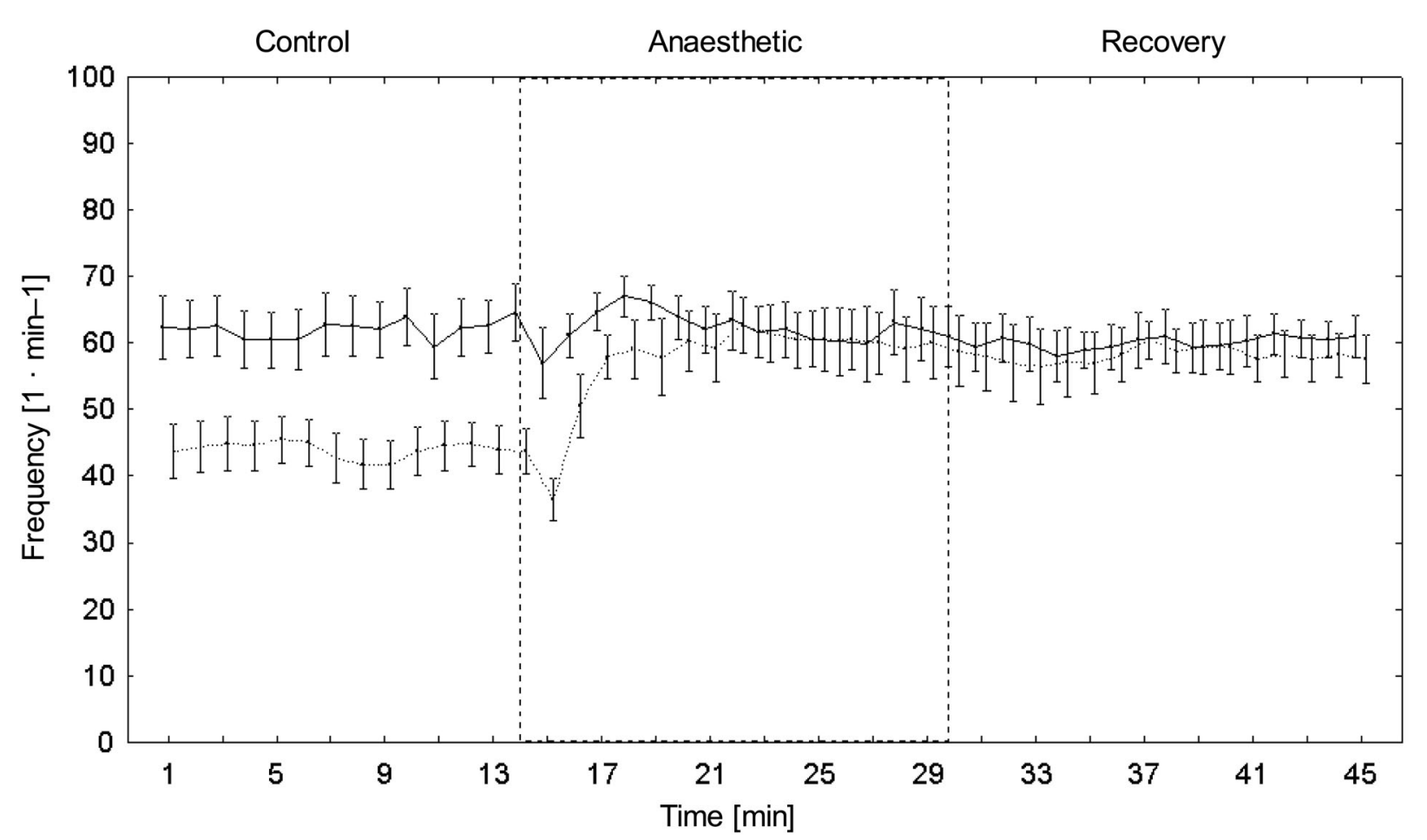

Fig. 1. Effect of MS-222 $\left(75 \mathrm{mg} \cdot \mathrm{L}^{-1}\right)$ on heartbeat (dotted line) and respiratory rhythm (solid line)

MS-222 is known to appear quickly in the central nervous system. As early as one minute after immersion, its presence can be detected in the brain (Hunn 1970, Hunn and Allen 1974). The fish heart constitutes a very sensitive organ reacting on all, even small, external stimuli. For instance, a flash of light, mechanical vibrations, salinity changes, pressure changes, or a touch can trigger arrhythmia, bradycardia, or even a total arrest of the heartbeat (Labat 1966, Cybulska et al. 1978).

The results of the present study revealed that MS-222 at 75,100 , and $125 \mathrm{mg} \cdot \mathrm{L}^{-1}$ caused a brief bradycardia followed by acceleration of the heartbeat persisting throughout the entire experiment. It appears that the observed temporary cardiac arrest in fish can be treated either as a spinal cord reflex or the effect of MS-222 action on higher levels of the nervous system.

Satchell (1991) suggested that tachycardia in fish is associated with the secretion of catecholamines from

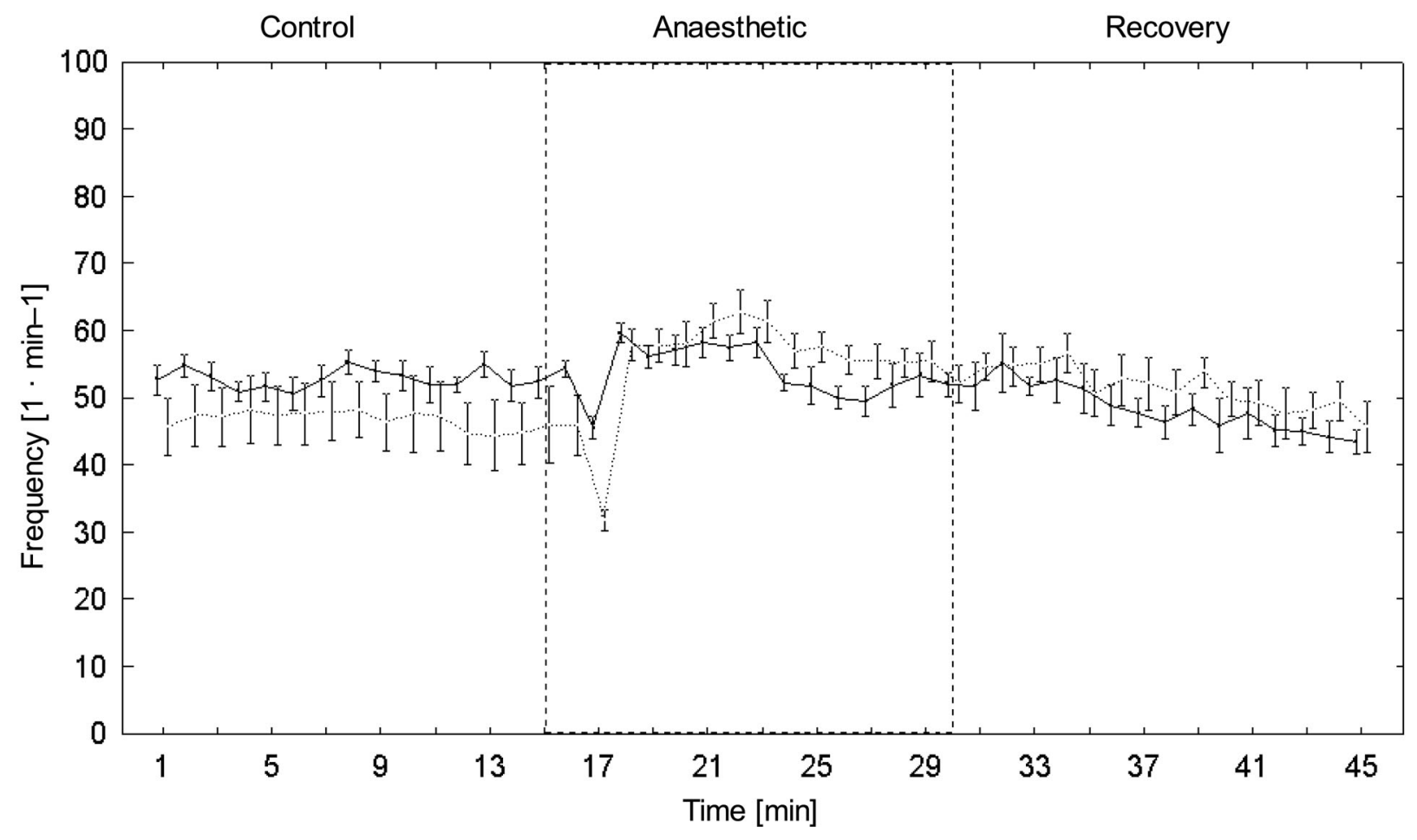

Fig. 2. Effect of MS-222 $\left(100 \mathrm{mg} \cdot \mathrm{L}^{-1}\right)$ on heartbeat (dotted line) and respiratory rhythm (solid line) 


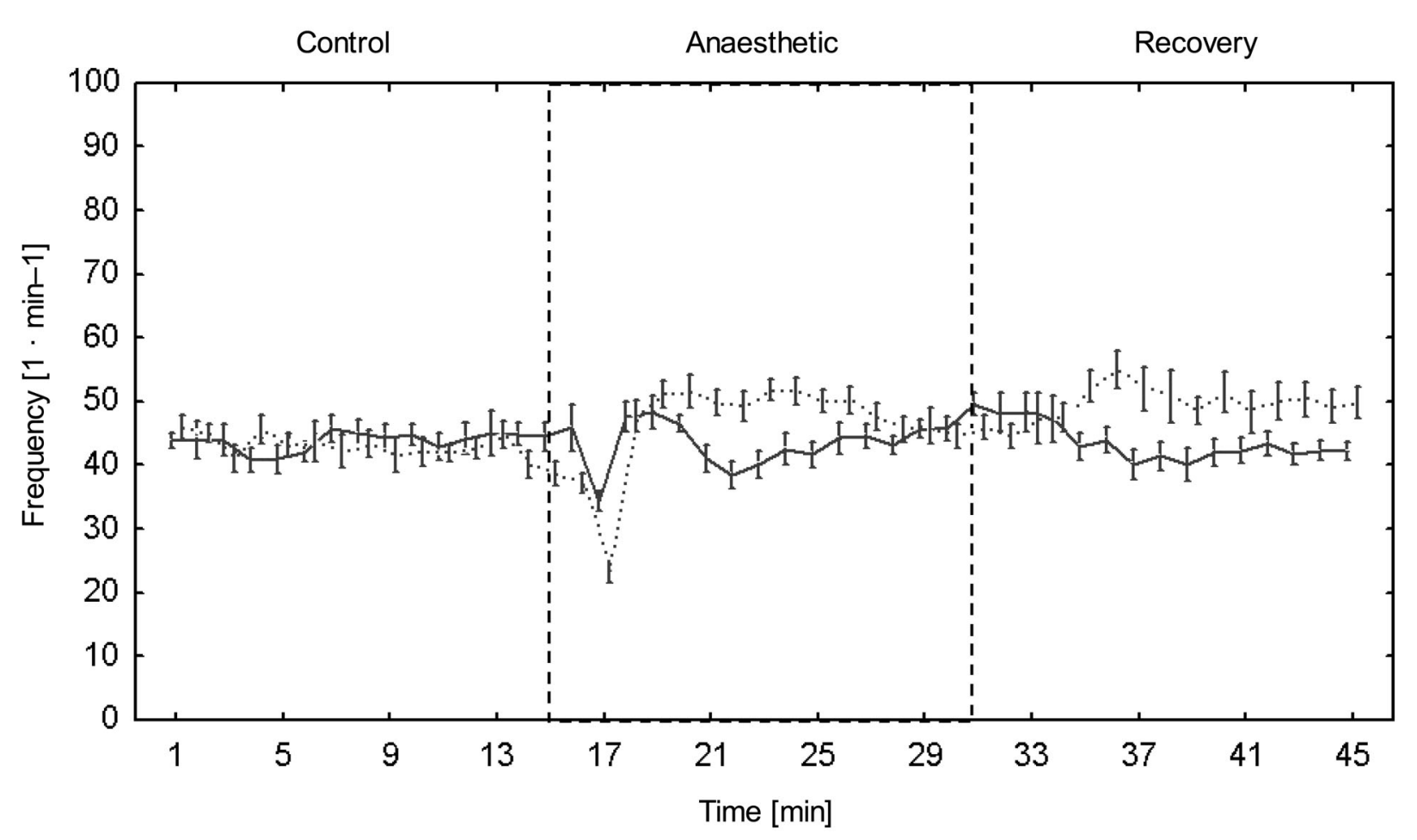

Fig. 3. Effect of MS-222 $\left(125 \mathrm{mg} \cdot \mathrm{L}^{-1}\right)$ on heartbeat (dotted line) and respiratory rhythm (solid line)

chromaffin tissue or from the endings of nerves stimulating automatic centres. An increase in heart rate within the first minutes of fish contact with MS-222 was also observed by Serfaty et al. (1959), who distinguished two periods of tachycardia: transient tachycardia, with higher amplitude and relatively short duration, followed soon by tachycardia proper. They assumed that the first symptom of heartbeat acceleration was due to fish contact with the anaesthetic, while the following one was an effect of MS222 circulation in the blood. Similar observations of two periods of tachycardia in fish exposed to MS-222 were described by Houston et al. (1971) and Ryan et al. (1993). Randall (1962) studying effects of various concentrations of MS-222 on tench, Tinca tinca, registered acceleration in the heart rate in the induction phase. Higher concentrations were associated with stronger tachycardia, although

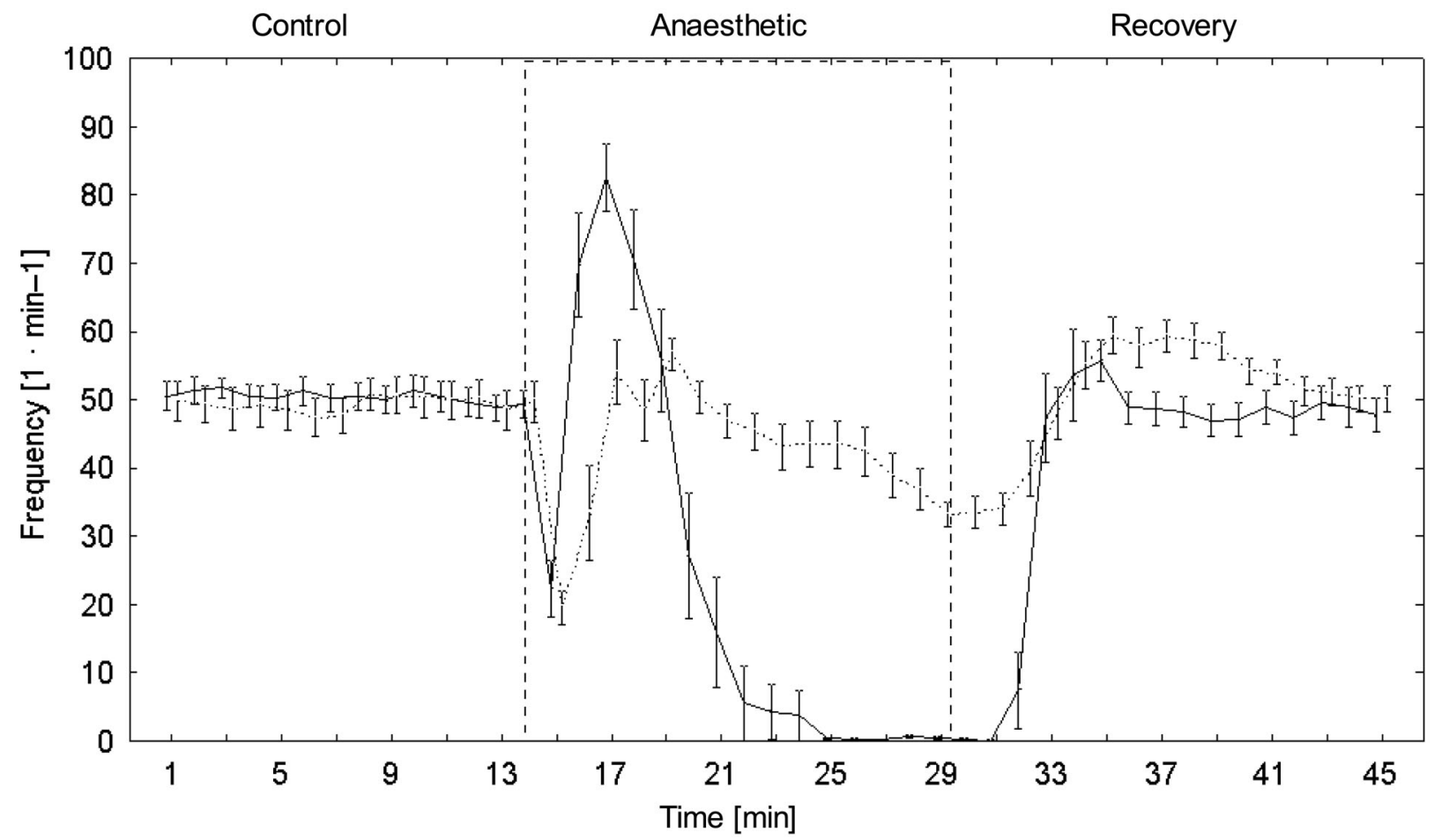

Fig. 4. Effect of MS-222 $\left(150 \mathrm{mg} \cdot \mathrm{L}^{-1}\right)$ on heartbeat (dotted line) and respiratory rhythm (solid line) 


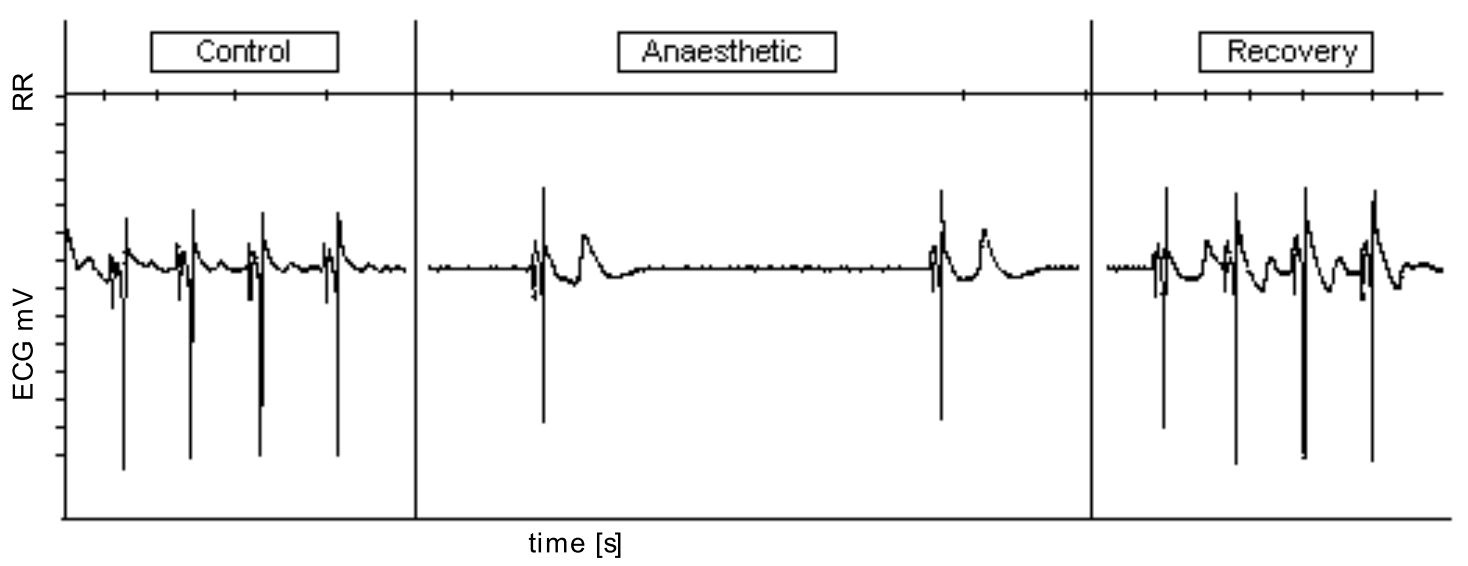

Fig. 5. ECG curve of carp, recorded during general anaesthesia with MS-222; irregular dots on the upper "axis" denote respiratory movements

exceeding $100 \mathrm{mg} \cdot \mathrm{L}^{-1}$ caused the collapse of respiratory function, arrhythmia and a decrease in heart rate. In the current study, a similar sequence of changes in heart rate was only observed at $150 \mathrm{mg} \cdot \mathrm{L}^{-1}$.

According to Serfaty et al. (1959), the effects accompanying gradual bradycardia caused by MS-222 were atrioventricular blocks, observed by ECG. In the present study there were no such symptoms. Decreasing frequency of respiratory movements was associated with increased amplitude and duration of the $\mathrm{T}$ wave (Fig. 5). In the recovering fish, the shape and amplitude of this wave quickly resumed its control value. Authors studying the electrical function of the fish heart all agree that the $\mathrm{T}$ wave is the most characteristic part of the ECG (Labat 1966, Mourad 1990). Differences in $\mathrm{T}$ wave shape can be related to different causes. Labat (1966) observed a substantial $\mathrm{T}$ wave enlargement at lower temperatures. Changes in $\mathrm{T}$ wave amplitude and shape may also result from acute anoxia ide anaesthesia (Mitsuda et al. 1982), or MS-222 anaesthesia (Labat 1996).

In the present study, a decrease in respiratory frequency was only recorded in the treatment with MS-222 at 150 $\mathrm{mg} \cdot \mathrm{L}^{-1}$. In the 11 th minute after introduction of MS-222 to the aquarium, there was a total apnoea which then persisted through the rest of the period of anaesthesia. After transferring the sedated fish to clean, well aerated water, the respiratory rhythm assumed control values after some 5 minutes, which coincided with the fish regaining their (Harms and Bakal 1994, Rantin et al. 1995), carbon-diox-

locomotor abilities.

Lower concentrations of MS-222 (75, 100, and $125 \mathrm{mg} \cdot \mathrm{L}^{-1}$ ) caused a state of deep anaesthesia without changing the respiratory rhythm. A slight decrease in respiratory frequency, associated with the signs of anxiety, was observed in the first minutes of the experiment. Later the respiratory rhythm stabilised on the level similar to that of control.

The depressive action of MS-222 on the respiratory centres of fish, translating into hypoxia, has been emphasised by a number of authors (Tyler and Hawkins 1981, Molinero and Gonzales 1995). It is commonly believed that anoxia during anaesthesia is an effect of diminished ability for oxygen acquisition, caused by the blockage of tissue respiration and an increased resistance to blood flow resulting from erythrocyte swelling and their accumulation in the gills (Modrzejewski 1965, Holeton and Randall 1967, Fromm at al. 1971).

According to many authors, it is symptomatic for MS-222 to quickly anaesthetise fishes (McFarland 1959, 1960, Ross and Ross 1984, Gilderhus and Marking 1987, Bowser 2001). The present results revealed that the sedation time period, from the moment of anaesthetic administration to the water until the loss of locomotor balance, decreased with the increase of anaesthetic concentration. Loss of equilibrium was observed within 5 minutes only at the higher concentrations $\left(125\right.$ and $\left.150 \mathrm{mg} \cdot \mathrm{L}^{-1}\right)$. The average time of recovery and regaining locomotor proficiency was 4 min for all concentrations tested.

Table 2

Times of losing and regaining locomotor balance recorded in carp exposed to MS-222; mean $(\bar{x}) \pm$ standard deviation $(s)$

\begin{tabular}{|c|c|c|c|c|}
\hline \multirow{3}{*}{$\begin{array}{c}\text { Anaesthetic } \\
\text { concentration } \\
{\left[\mathrm{mg} \cdot \mathrm{L}^{-1}\right]}\end{array}$} & \multicolumn{2}{|c|}{ Loss of balance } & \multicolumn{2}{|c|}{ Regaining balance } \\
\hline & $\bar{x}$ & $s$ & $\bar{x}$ & $s$ \\
\hline & [min] & {$[\mathrm{min}]$} & {$[\mathrm{min}]$} & {$[\mathrm{mim}]$} \\
\hline 75 & 8.37 & 3.08 & 4.91 & 1.97 \\
\hline 100 & 5.79 & 0.92 & 4.58 & 1.38 \\
\hline 125 & 3.78 & 1.00 & 4.48 & 1.88 \\
\hline 150 & 3.73 & 1.12 & 4.28 & 1.17 \\
\hline
\end{tabular}


Taking into account the induction and recovery times, in view of the criteria used for assessing anaesthetics, MS222 at 125 and $150 \mathrm{mg} \cdot \mathrm{L}^{-1}$ induced anaesthesia within 5 minutes. At these concentrations, MS-222 fulfilled the criteria of Hseu et al. (1998) and the period of induction slightly exceeded the period of 3 minutes proposed as the criterion by Gilderhus and Marking (1987).

\section{ACKNOWLEDGEMENTS}

The presently reported study was financed by the Agricultural University of Szczecin, Poland in the form of a $\mathrm{PhD}$ research grant to R.D.

\section{REFERENCES}

Bowser P.R. 2001. Anesthetic options for fish. International Veterinary Information Service (www.ivis.org), Ithaca, New York, USA.

Cybulska N., Muzykiewicz J., Węgrzynowicz R. 1978. Wpływ bodźców fizycznych na zmiany EKG u węgorzy Auguilla anguilla L. [Effect of physical stimuli on changes of ECG in eel, Auguilla anguilla L.] Zeszyty Naukowe Akademii Rolniczej w Szczecinie (70): 18-22.

Fromm P.O., Richards B.D., Hunter R.C. 1971. Effects of some insecticides and MS-222 on isolated perfused gills of trout. Progressive Fish Culturist 33: 138-152.

Gilderhus P.A., Marking L.L. 1987. Comparative efficacy of 16 anesthetic chemicals on rainbow trout. North American Journal of Fisheries Management 7: 288-292.

Harms C.A., Bakal B.S. 1994. Techniques in fish anesthesia. pp. 22-27. In: Junge R.E. (ed.) Proceedings of the American Association of Zoo Veterinarians and Association of Reptilian and Amphibian Veterinarians, Annual Conference.

Holeton G.F., Randall D.J. 1967. Changes in blood pressure in the rainbow trout during hypoxia. The Journal of Experimental Biology 46: 297-305.

Houston A.H., Madden J.A., Woods R.J., Miles H.M. 1971. Some physiological effects of handling and tricaine methanesulphonate anaesthetization upon the brook trout, Salvelinus fontinalis. Journal of the Fisheries Research Board of Canada 28: 625-633.

Hseu J.R., Yeh S.L., Chu Y.T., Ting Y.Y. 1998. Comparison of efficacy of five anesthetics in goldlined sea bream, Sparus sarba. Acta Zoologica Taiwanica 9: 1-7.

Hunn J.B. 1970. Dynamics of MS-222 in the blood and brain of freshwater fishes during anesthesia. Investigations in Fish Control, U.S. Department of the Interior. Bureau of Sport Fisheries and Wildlife (42): 1-8.

Hunn J.B., Allen J.L. 1974. Movement of drugs across the gills of fishes. Annual Review of Pharmacology 14: 47-54.

Labat R. 1966. Electrocardiologie chez les poissons téléostéens: influence de quelques facteurs écologiques. $\mathrm{PhD}$ thesis, Université de Toulouse. Edouard Privat, Libraire-Éditeur, Toulouse, France.

McFarland W.N. 1959. A study of the effects of anesthetics on the behavior and physiology of fishes. Publications of the Institute of Marine Science, The University of Texas Marine Science Institute, Port Aransas, Texas 6: 23-55.

McFarland W.N. 1960. The use of anaesthetics for handling and the transport of fishes. California Fish and Game 46:
407-431.

Mitsuda H., Ueno S., Mizuno H., Ueda T., Fujikawa H., Nohara T., Fukada C. 1982. Levels of $\mathrm{CO}_{2}$ in arterial blood of carp under carbon dioxide anesthesia. Journal of Nutritional Science and Vitaminology 28: 35-39.

Modrzejewski E. 1965. Badania nad wpływem różnego rodzaju dożylnie stosowanych środków narkotycznych na zawartość tlenu i dwutlenku węgla we krwi zwierząt doświadczalnych. [Studies on the effect of various intravenous narcotics on the carbon dioxide contents in the blood of experimental animals.] Acta Physiologica Polonica 16: 535-549.

Molinero A., Gonzalez J. 1995. Comparative effects of MS-222 and 2-phenoxyethanol on gilhead sea bream (Sparus aurata L.) during confinement. Comparative Biochemistry and Physiology A 111: 405-414.

Mourad M.H. 1990. Effects of lindane on the electrocardiogram, heart rate and respiratory rate of the eel, Anguilla anguilla $\mathrm{L}$. at different temperatures. $\mathrm{PhD}$ thesis, Agricultural University of Szczecin, Poland.

Randall D.J. 1962. Effects of an anesthetic on the heart and respiration of teleost fish. Nature 195: 506-508.

Rantin F.T., Kalinin A.L., Guerra C.D., Maricondi-Massari M., Verzola R.M. 1995. Electrocardiographic characterization of myocardial function in normoxic and hypoxic teleosts. Brazilian Journal of Medical and Biological Research 28: 1277-1288.

Ross L.G., Ross B. 1984. Anaesthetic and sedative techniques for fish. Institute of Aquaculture, University of Stirling, Stirling, Scotland.

Ryan S.N., Davie P.S., Gesser H., Wells R.M.G. 1993. The effect of MS-222 on paced ventricle strips and the perfused heart of rainbow trout, Oncorhynchus mykiss. Comparative Biochemistry and Physiology C 106: 549-553.

Satchell G.H. 1991. Physiology and form of fish circulation. Cambridge University Press, Cambridge, New York, Port Chester.

Serfaty A., Labat R., Quillier R. 1959. Les réactions cardiaques chez la carpe (Cyprinus carpio) au cours d'une anesthésie prolongée. Hydrobiologia. Acta Hydrobiologica Hydrographica et Protistologica 13: 1-2.

Schoettger R.A., Julin M. 1967. Efficacy of MS-222 as an anesthetic on four salmonids. U.S. Fish and Wildlife Service Investigations in Fish Control 13: 1-15.

Soivio A., Nyholm K., Huhti M. 1977. Effects of anaesthesia with MS 222, neutralized MS 222 and benzocaine on the blood constituents of rainbow trout, Salmo gairdneri. Journal of Fish Biology 10: 91-101.

Tytler P., Hawkins A.D, 1981. Vivisection, anaesthetics and minor surgery. pp: 247-278. In: Hawkins A.D. (ed.) Aquarium systems. Academic Press, New York.

Wedemeyer G. 1970. Stress of anesthesia with MS-222 and benzocaine in rainbow trout (Salmo gairdneri). Journal of the Fisheries Research Board of Canada 27: 909-914.

Received: 4 September 2005 Accepted: 17 November 2005 